\title{
Influence of the Ratio IA/PA and Volatile Acids in the Monitoring of UASB Reactor in the Treating of Swine Waste Water
}

\author{
Luciano S. Rodrigues*, Israel J. Silva, Paulo R. Oliveira, Ana C. A. Pinto, Camila A. Lima \\ Escola de Veterinária, Universidade Federal de Minas Gerais, Belo Horizonte, Brazil \\ Email: ${ }^{\text {Isantosrodrigues@gmail.com }}$
}

Received 18 February 2014; revised 15 March 2014; accepted 12 April 2014

Copyright (C) 2014 by authors and Scientific Research Publishing Inc.

This work is licensed under the Creative Commons Attribution International License (CC BY). http://creativecommons.org/licenses/by/4.0/

CC) (i) Open Access

\section{Abstract}

This paper presents the influence of the ratio IA/PA and concentration of volatile acids (TVA) in the operational stability of a UASB reactor treating swine waste water. The treatment system in real scale was constituted of decanter, followed by the UASB reactor with volume of $7.4 \mathrm{~m}^{3}$ and $11.5 \mathrm{~m}^{3}$, respectively. It has been observed a large oscillation of the ratio IA/IP in the UASB reactor with an average value of 0.39 , and average efficiency of removal of BOD and COD of 79.8 and $79.3 \%$, respectively, at the start, dropping to 0.12 in the continuity of the experiment, including during overload, in which the removal efficiencies of COD and BOD reached values below $10 \%$. The TVA average values were $913 \mathrm{mg} \cdot \mathrm{L}^{-1}$ in the UASB reactor, increasing considerably in the overload period, reaching values higher than $4500 \mathrm{mg} \cdot \mathrm{L}^{-1}$, indicating an accumulation of volatile acids and reduced efficiency of the UASB reactor in removal of organic matter. We conclude that the monitoring of the values of the ratio IA/PA and TVA is very useful instruments and easy to determine in the monitoring of the UASB reactor, enabling to predict possible instabilities in the reactor, allowing corrective actions in a timely manner.

\section{Keywords}

Operational Stability, Pig Manure, Anaerobic Digestion

\section{Introduction}

The swine is undoubtedly an activity of great importance in the Brazilian agribusines context. However, its op-

\footnotetext{
${ }^{*}$ Corresponding author.
}

How to cite this paper: Rodrigues, L.S., Silva, I.J., Oliveira, P.R., Pinto, A.C.A. and Lima, C.A. (2014) Influence of the Ratio IA/PA and Volatile Acids in the Monitoring of UASB Reactor in the Treating of Swine Waste Water. Journal of Water Resource and Protection, 6, 526-531. http://dx.doi.org/10.4236/jwarp.2014.65051 
eration is considered by environmental organizations as an "activity potentially causing environmental degradation”, being framed as of great polluter potential [1].

The high generation of waste from the swine has as its main destination, the mere placement in soil. This practice makes that, in many situations, an excess of nutrients occurs, metals and pathogenic organisms in the soil, making it difficult to absorb at the same rate at which these substances are applied, resulting in leaching and percolation of this waste to the bodies of surface water and groundwater, causing pollution [2].

One of the ways to treat wastewater generated in this type of activity is through the use of an up flow anaerobic sludge blanket (UASB), which can be built and operated to minimize the treatment costs. This kind of reactor, as other anaerobic systems, produces biogas as a byproduct, which can be used as an energy source.

To enjoy the benefits of the anaerobic digestion, anaerobic reactors must be operated properly and for that there is the need for effective monitoring by parameters that indicate safely and quickly the occurrence of disturbances in their performance [3].

According to Oliveira et al. [4], to achieve success with the anaerobic treatment, the reactors must be operated properly, identifying with speed and security disturbances in their performance. Several tests and determinations have been proposed to identify instabilities in anaerobic reactors, such as: biogas production and composition; reductions in BOD, COD and volatile solids; measure of ATP; methanogenic dehydrogenase activity, and sludge's fluorescence. However, some measures may have a long response time and others are very laborious and costly. The ideal measures for monitoring of anaerobic digestion should be simple to perform, fast and sensitive enough to indicate the disorder before the onset of the collapse of the digester.

One can obtain a satisfactory performance of an anaerobic system operating with stability in the $\mathrm{pH}$ range between 6.5 and 8.5 . In this range, the $\mathrm{pH}$ is controlled by the buffer capacity of the system, related to the balance of carbonates, mainly represented by the alkalinity due to bicarbonate, which is crucial for the stability of the anaerobic digestion of organic waste [3].

According to Chernicharo [5] systematic verification of bicarbonate alkalinity is more effective than $\mathrm{pH}$ monitoring, because while the $\mathrm{pH}$ scale is logarithmic, the alkalinity scale is linear. Thus, small $\mathrm{pH}$ lowering imply in the consumption of a large amount of alkalinity, reducing the buffering capacity of the medium.

The total alkalinity in anaerobic systems is determined by titration of the sample to $\mathrm{pH} 4.30$, which measures the buffer capacity due to bicarbonate and also the volatile acids [6]. To avoid the inclusion of volatile acids in the alkalinity value, Jenkins et al. (1983) proposed the titration of the sample to $\mathrm{pH} 5.75$, for it would have the determination of $80 \%$ of bicarbonate and only $20 \%$ of volatile acids. Ripley et al. [6] defined the alkalinity due to bicarbonate of the partial alkalinity (PA) and due to volatile acids denominated intermediate alkalinity (IA). According to the authors the ratio IA/PA with values greater than 0.30 indicates the occurrence of disturbances in the process of anaerobic digestion [3].

Foresti [7] reports that the stability of the anaerobic digestion process may occur for values of ratio IA/PA different from 0.3 , and it would be prudent to check for each particular case.

Another alternative for determining the portions of alkalinity is by the method of Kapp, which constitutes in titration of the sample in three stages: to $\mathrm{pH} 5.0$, to $\mathrm{pH} 4.3$ and to $\mathrm{pH} 4.0$. These three successive titrations enable the determination of total alkalinity (TA), of bicarbonate alkalinity (BA) and of alkalinity due to volatile acids (VAA) [5].

The measurement of total volatile acids (TVA) is the parameter which provides, together with the measurement of the volume of produced gases, the most immediate indication of the operation of the process. The TVA can accumulate in the digesters due to organic overload, toxic and hydraulic causing instabilities in the anaerobic reactors.

Imai et al. [8] cited by Pereira-Ramirez et al. (2004), stated that in the UASB reactor, the activity of acidogenic bacteria, which produce the TVA, and of the methanogenic archaea that form methane from the TVA and hydrogen, can be easily inhibited by low $\mathrm{pH}$ as a result of the accumulation of TVA.

The aim of this study was to check the possible association between the ratio IA/PA and concentration of TVA with the performance of the UASB reactor, with regard to the removal efficiency and effluent concentrations of BOD and COD in an UASB reactor operated at full scale treating effluent from swine wastewater.

\section{Materials and Methods}

\subsection{Study Area}

The study was conducted in the swine of the Experimental Farm Professor Hélio Barbosa of the Veterinary 
School, Federal University of Minas Gerais (UFMG), located in Igarapé/MG. The treatment system in full scale consisted of a decanter, followed by a UASB reactor, with volumes of $7.4 \mathrm{~m}^{3}$ and $11.5 \mathrm{~m}^{3}$, respectively, as the flowchart shown in Figure 1.

\subsection{Treatment Plant}

The treatment system in full scale was designed to meet the sectors of nursery, growing and finishing of the swine with capacity for 400 animals. The feeding of waste generated was performed by gravity through the channels.

The UASB reactor was inoculated with sludge from an anaerobic pond previously employed in the treatment of swine wastewater. The initial biological load (BL) was approximately $0.37 \mathrm{~kg}$ CODkgVTS ${ }^{-1} \cdot \mathrm{d}^{-1}$.

The process of inoculation was carried out through a tractor with a liquid manure tank, which captured $6.5 \mathrm{~m}^{3}$ of sludge from the bottom of the anaerobic pond and pumped to the UASB reactor. After inoculation, the biomass remained at rest for a period of 24 hours. After the rest period was started the feeding with waste, using $30 \%$ of the design load, which was then gradually increased until it reaches full load.

\subsection{Monitoring Program}

Samples of influent and effluent of the decanter and the UASB reactor were collected three times a week during them morning, throughout the period of the cleaning of the swine. Composite samples were carried out in glass bottles previously identified from the single samples collected every 15 minutes.

The system was monitored for 40 weeks, through the following physicochemical parameters: air temperature, liquid temperature, $\mathrm{pH}$, biochemical oxygen demand(BOD), chemical oxygen demand(COD), total suspended solids (TSS), volatile suspended solids(VSS), as described in Standard Methods for Examination of Water and Wastewater(AWWA /APHA/WEF, 1998).

The measures of partial alkalinity (PA) and intermediate (IA) were performed according to the methodology described by Jenkins et al. [9] and Ripley et al. [6], obtaining PA using titration of the original sample until $\mathrm{pH}$ 5.75 and IA with $\mathrm{pH}$ titration 5.75 to 4.30 . The analysis of total volatile acids (TVA) is according to Dillalo \& Albertson [10].

\section{Results and Discussion}

The Table 1 presents the average values of physicochemical parameters obtained during 40 weeks of monitoring the influent and effluent of the decanter and the UASB reactor.

The UASB reactor had average removal efficiencies of BOD and COD of $87 \%$ and $85 \%$, respectively, for organic volumetric loads (OVL) applied ranging from 1.1 to $17.5 \mathrm{~kg} \mathrm{COD} \mathrm{m}{ }^{-3} \cdot \mathrm{d}^{-1}$ and HDT ranging from 1,7 to 4.1 days.

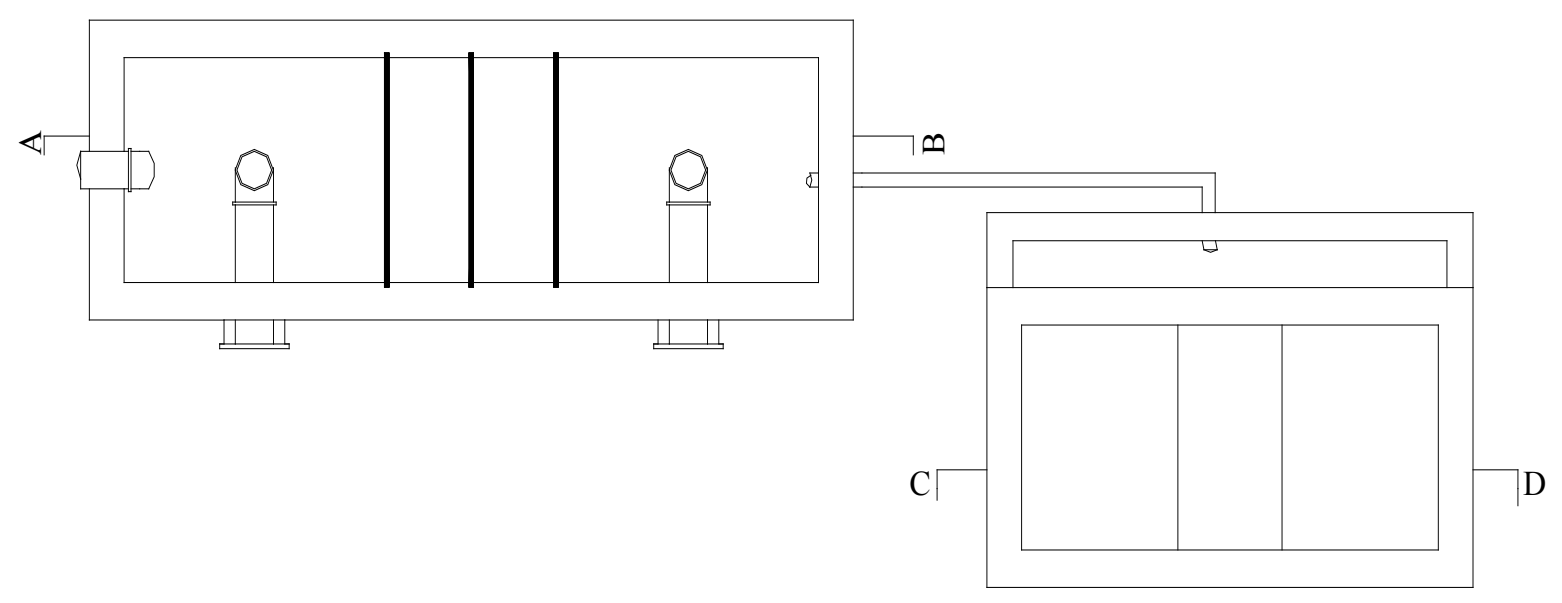


Table 1. Average values of physicochemical parameters of the influent and effluent of the decanter and the UASB reactor during the experimental period.

\begin{tabular}{cccc}
\hline Parâmeter & Influent & Decanter Effluent & UASB Reactor Effluent \\
\hline Temperature $\left({ }^{\circ} \mathrm{C}\right)$ & $20 \pm 3$ & $22 \pm 3$ & $22 \pm 3$ \\
$\mathrm{pH}$ & $6.99 \pm 0.32$ & $6.53 \pm 0.33$ & $7.07 \pm 0.24$ \\
$\mathrm{TA}\left(\mathrm{CaCO}_{3} \mathrm{mg} \cdot \mathrm{L}^{-1}\right)$ & $3101 \pm 951$ & $3854 \pm 759$ & $3700 \pm 379$ \\
$\mathrm{IA}\left(\mathrm{CaCO}_{3} \mathrm{mg} \cdot \mathrm{L}^{-1}\right)$ & $1636 \pm 632$ & $2272 \pm 658$ & $524 \pm 429$ \\
$\mathrm{PA}\left(\mathrm{CaCO} 3 \mathrm{mg} \cdot \mathrm{L}^{-1}\right)$ & $1476 \pm 624$ & $1582 \pm 446$ & $3177 \pm 777$ \\
$\mathrm{Ratio} \mathrm{IA} / \mathrm{PA}$ & $1.24 \pm 0.64$ & $1.58 \pm 0.70$ & $0.20 \pm 0.22$ \\
$\mathrm{TVA}\left(\mathrm{CaCO} 3 \mathrm{mg} \cdot \mathrm{L}^{-1}\right)$ & $2875 \pm 921$ & $2953 \pm 638$ & $913 \pm 207$ \\
$\mathrm{BOD}\left(\mathrm{mg} \cdot \mathrm{L}^{-1}\right)$ & $11129 \pm 4244$ & $6447 \pm 2211$ & $790 \pm 500$ \\
$\mathrm{COD}\left(\mathrm{mg} \cdot \mathrm{L}^{-1}\right)$ & $31334 \pm 11143$ & $14778 \pm 7183$ & $1818 \pm 916$ \\
$\mathrm{TSS}\left(\mathrm{mg} \cdot \mathrm{L}^{-1}\right)$ & $8595 \pm 4847$ & $2729 \pm 1431$ & $854 \pm 493$ \\
$\mathrm{VSS}\left(\mathrm{mg} \cdot \mathrm{L}^{-1}\right)$ & $6487 \pm 3967$ & $2314 \pm 1293$ & $727 \pm 411$ \\
\hline
\end{tabular}

The average removal efficiencies of TSS in the decanter and in the UASB reactor were $62.7 \%$ and $63.1 \%$, respectively. For VSS the average removal efficiencies were $55 \%$ for the decanter and $62 \%$ for the UASB reactor. The performance of the treatment system in the removal of TSS and VSS was $88 \%$ and $85 \%$, respectively.

Observed was an excellent performance of the decanter in the removal of TSS and VSS. The UASB reactor showed a similar efficiency to the decanter, however, was observed during the entire experimental period the entrainment of solid particles of the sludge blanket, which escaped together with the effluent.

The average values of TA in the effluent from the decanter and in the UASB reactor were very close showing little variation of this parameter while passing by the UASB reactor. However, when evaluating its components is, observed a different behavior. For the IA occurs a reduction of the effluent from the decanter to the UASB reactor, due to the consumption of volatile acids in the process, while the reverse was observed for PA, that is, increase of the concentration of the effluent from the decanter to the UASB reactor, due to the generation of alkalinity bicarbonate (Figure 2).

In Figure 3 was observed two distinct phases of ratio IA/PA in the UASB reactor, with values between 0.14 and 1.28 at the beginning of the experiment (first 60 days) related to starting, and values of IA/PA ranging from 0.05 to 0.47 in the remainder of the experiment. In the first phase there was a large variation over ratio IA/PA in the UASB reactor with an average value of 0.39 , and average efficiency of removal of BOD and COD of 79.8 and $79.3 \%$, respectively. In the second phase the average ratio IA/PA was 0.12 and the efficiency of removal of BOD and COD was $86.2 \%$ and 83.1 , respectively.

In the period from $10 / 09$ to $02 / 10 / 2007$ occurred a hydraulic and organic overload in the system, with a reduction in BOD removal efficiency $(61.9 \%)$ and COD $(53.45 \%)$ of the UASB reactor, reaching even negative values. In this period the ratio IA/PA was 0.14 .

In Figure 4, it is observed that the TVA concentration significantly reduced of the effluent from the decanter to the UASB reactor indicating that these acids were consumed at the same rate that they were produced, characterizing the generation of alkalinity, with buffering of the UASB reactor and not allowing accumulation of volatile acids.

Gerardi [11] recommends values of TVA in the range of 50 to $500 \mathrm{mg} \cdot \mathrm{L}^{-1}$ to occur ability in the anaerobic process, but the average values of TVA in the reactor during the experiment was $913 \mathrm{mg} \cdot \mathrm{L}^{-1}$, a fact that did not affect the reactor performance.

During the overload, the concentration of TVA in the UASB reactor increased considerably reaching values of $4680 \mathrm{mg} \cdot \mathrm{L}^{-1}$, showing that there is an accumulation of volatile acids and reduced efficiency of the UASB reactor in the removal of COD and BOD.

In Figure 4 and Figure 5 are shown the relationships between the removal efficiencies of BOD and COD in the effluent with the concentration of TVA and the ratio IA/PA. It can be observed a large ratio between the 


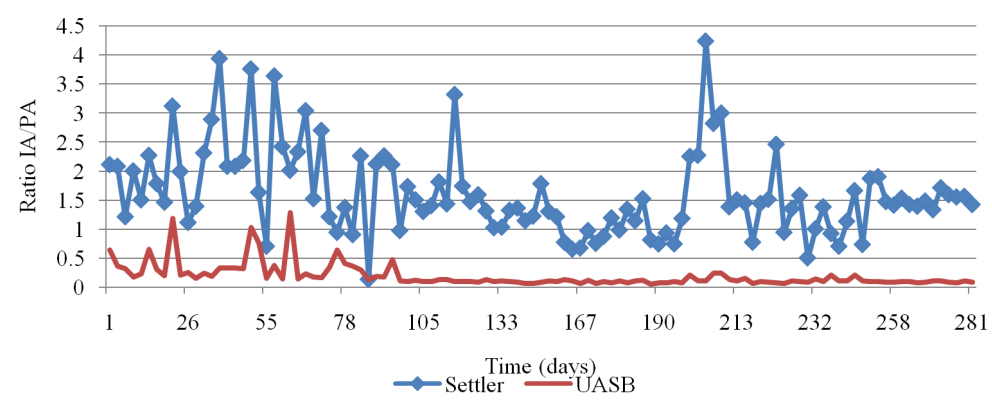

Figure 2. Variationsof the ratio IA/PA of the effluent from the decanter and the UASB reactor during the experimental period.

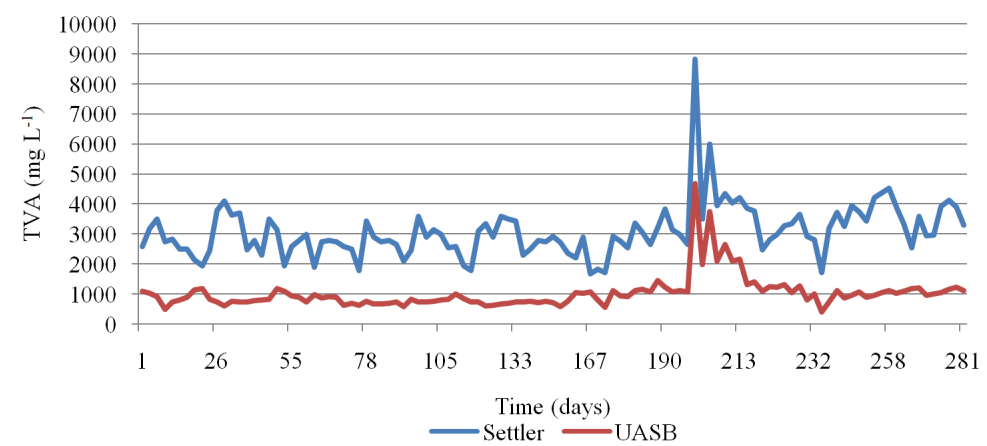

Figure 3. Variations of TVA of the effluent from the decanter and UASB reactor during the experimental period.
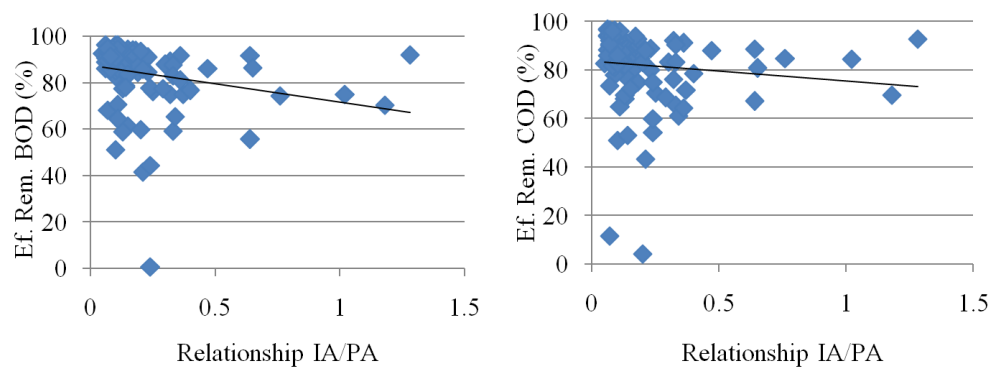

Figure 4. Scatter plot of the relationship between removal efficiency of BOD and COD with the relationship IA/PA in the UASB reactor during the experimental period.
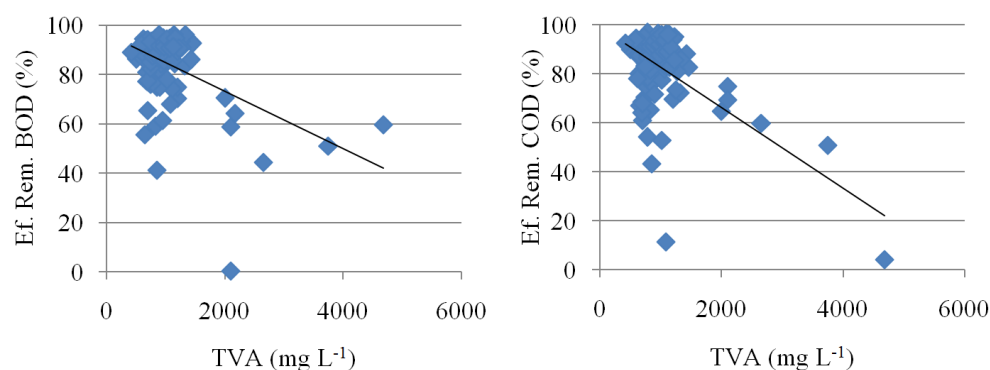

Figure 5. Scatter plot of the relationship between removal efficiency of BOD and COD with the TVA in the UASB reactor during the experimental period.

concentration of TVA the reactor and its performance. As the concentration of TVA increases, is observed a reduction of the efficiency of removal of COD and BOD in the effluents. This is due to the accumulation of vola- 
tile acids in the reactor.

It was observed that the monitoring of TVA was crucial to identify operational problems in the UASB reactor, and take appropriate action to solve such problems. Another important aspect of the TVA in this experiment was its high values, higher than the recommended by the literature, but that did not mean operational instability of the UASB reactor.

The ratio IA/PA presented values well below to 0.30 during a big part of the experiment, including in the overload period, in which was not able to identify the instability of the UASB reactor in this period.

The monitoring of the alkalinity values and of TVA can be considered as a very useful instrument and easy to determine in the monitoring of the UASB reactor, enabling to predict possible instabilities in the reactor, allowing corrective actions in a timely manner.

\section{Conclusion}

Monitoring the values of the ratio AI/AP and TVA proved to be an effective tool in the monitoring of the UASB reactor, indicating the possible instabilities of the process, so that steps can be taken to resolve the problem and thereby avoid a drop in the efficiency of the reactor.

\section{Acknowledgements}

To the Foundation for Research Support of Minas Gerais (FAPEMIG) and the Federal University of Minas Gerais (UFMG).

\section{References}

[1] Palhares, J.C.P. and Calijuri, M.C. (2006) Impacto de sistemas de produção suinícola naqualidade dos recursos hídricos. Embrapa Suínos e Aves, Concórdia, 2p.

[2] Perdomo, C.C., Oliveira, P.A.V.O. and Kunz, A. (2003) Sistema de tratamento de dejetos de suínos: inventário tecnológico. Embrapa Suínos e Aves, Concórdia, 83 p. (Documents, 85).

[3] Iamamoto, C.Y., de Oliveira, R.A. and de Lucas Júnior, J. (2002) Alcalinidade como medida de monitoramento do desempenho de Reatores Anaeróbios de Fluxo Ascendente com Manta de Lodo (UASB), tratando águas residuárias de suinocultura. Engenharia Agrícola, 22, 118-126.

[4] de Oliveira, R.A. (1997) Efeito da concentração de sólidos suspensos do afluente no desempenho e características do lodo de reatores anaeróbios de fluxo ascendente com manta de lodo tratando águas residuárias de suinocultura. São Carlos, 1997. 359 f. Tese. (Doutorado em Hidráulica e Saneamento)—Escola de Engenharia de São Carlos, Universidade de São Paulo, São Carlos.

[5] Chernicharo, C.A.L. (2007) Reatores Anaeróbios. 2nd Edition, DESA, UFMG, Belo Horizonte, 380 p. (Princípios do TratamentoBiológico de ÁguasResiduárias, v. 5).

[6] Ripley, L.E., Boyle, W.C. and Converse, J.C. (1986) Improved Alkalimetric Monitoring for Anaerobic Digestion of High-Strength Wastes. Journal WPCF, 48, 406-411.

[7] Foresti, E. (1994) Fundamentos do processo de digestão anaeróbia. In: Seminário Latino Americano. 3, Montevidéo. Anais..., Montevidéo, 97-110.

[8] Imai, T., Ukita, M., SEKINE, M. et al. (2001) A Study on an Improved Circulation Method in UASB Reactor for High Loading Operation and Effective Use of Its Alkalinity. In: World Congress Anaerobic Digestion, 9, Antuérpia. Proceedings...Technological Institute, Antuérpia, v.1., 699-704.

[9] Jenkins, S.R., Morgan, J.M. and Sawyer, C.L. (1983) Measuring Anaerobic Sludge Digestion and Growth by a Simple Alkalimetric Titration. Journal WPCF, 55, 448-453.

[10] Dilallo, R. and Albertison, O.E. (1961) Volatile Acids by Direct Titration. Journal Water Pollution Control Federation, 33, 356-365.

[11] Gerardi, M.H. (2003) The Microbiology of Anaerobic Digesters. Jon Wiley \& Sons, Hoboken, 130 p. http://dx.doi.org/10.1002/0471468967 